\title{
Dominees op de markt
}

Citation for published version (APA):

Maijoor, S. J. (1995). Dominees op de markt. Datawyse / Universitaire Pers Maastricht. https://doi.org/10.26481/spe.19951208sm

Document status and date:

Published: 08/12/1995

DOI:

10.26481/spe.19951208sm

Document Version:

Publisher's PDF, also known as Version of record

\section{Please check the document version of this publication:}

- A submitted manuscript is the version of the article upon submission and before peer-review. There can be important differences between the submitted version and the official published version of record.

People interested in the research are advised to contact the author for the final version of the publication, or visit the DOI to the publisher's website.

- The final author version and the galley proof are versions of the publication after peer review.

- The final published version features the final layout of the paper including the volume, issue and page numbers.

Link to publication

\footnotetext{
General rights rights.

- You may freely distribute the URL identifying the publication in the public portal. please follow below link for the End User Agreement:

www.umlib.nl/taverne-license

Take down policy

If you believe that this document breaches copyright please contact us at:

repository@maastrichtuniversity.nl

providing details and we will investigate your claim.
}

Copyright and moral rights for the publications made accessible in the public portal are retained by the authors and/or other copyright owners and it is a condition of accessing publications that users recognise and abide by the legal requirements associated with these

- Users may download and print one copy of any publication from the public portal for the purpose of private study or research.

- You may not further distribute the material or use it for any profit-making activity or commercial gain

If the publication is distributed under the terms of Article $25 \mathrm{fa}$ of the Dutch Copyright Act, indicated by the "Taverne" license above, 


\title{
DOMINEES OP DE MARKT
}

\author{
Een economische analyse van de markt, \\ het kantoor en het controleproces van accountants
}

\section{Rede}

in verkorte vorm uitgesproken bij de aanvaarding van het ambt van hoogleraar Bedrijfseconomie, in het bijzonder Analyse van Externe Berichtgeving en van bijzonder hoogleraar NOvAA Accountancy, in het bijzonder de Accountancy van het Midden- en Kleinbedrijf, aan de Rijksuniversiteit Limburg op vrijdag 8 december 1995

\author{
door
}

Dr. S.J. Maijoor

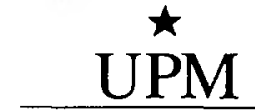

UNIVERSITAIRE PERS MAASTRICHT 
$P=145920534$

Universitisbilatiotheok

Rilksuniversitet Limburo 
Mijnheer de Rector Magnificus,

Zeer gewaardeerde toehoorders,

In mijn oratie wil ik u een economische analyse aanbieden van de markt, het kantoor en het controleproces van accountants. Ik hoop u daarmee vanmiddag van de volgende twee gedachten te kunnen overtuigen. Ten eerste wil ik u ervan overtuigen dat de activiteiten van accountants zich uitstekend lenen voor economische analyses, net zoals dat geldt voor vele andere diensten en produkten. Ten tweede wil ik u ervan overtuigen dat marktwerking een grotere invloed heeft gekregen op de activiteiten van accountants. De effecten van marktwerking zijn in Nederland het meest zichtbaar in het segment van de kleinere cliënten en de kleinere accountantskantoren.

De toepassing van de economische wetenschap op activiteiten van accountants lijkt vanzelfsprekend. Echter, tot enkele jaren geleden was de aanduiding "markt voor accountantscontrole" een ongebruikelijke term. Bij voorkeur werden termen als "het beroep" en "de professie" gebruikt. De reden hiervoor is duidelijk. Het belangrijkste dat accountants aanbieden is vertrouwen. Accountants bestuderen intensief de financiën van een onderneming en externe belanghebbenden moeten erop kunnen vertrouwen dat de rapportage daarover onafhankelijk en betrouwbaar is. De accountant werd ook wel de vertrouwensman' in het economisch-maatschappelijk verkeer genoemd. Kortom, hij was de dominee op financieel-economisch gebied. Bij dit beeld van de accountant past niet het beeld van de koopman die op de markt zijn diensten aanbiedt, die moet concurreren met andere koopmannen en die met

'Omwille van de eenvoud zal ik in mijn oratie alleen in de mannelijke vorm over de accountant spreken, ook al zijn er steeds meer vrouwelijke accountants. $\mathrm{Zij}$ vormen nog wel een minderheid. 
Dominees op de markt

zijn kopers onderhandelt over de prijs van zijn diensten. Echter, in mijn oratie zal ik $u$ laten zien dat het perspectief van de accountant als koopman nuttig kan zijn.

Om u enige houvast te bieden zal ik u de lijn van mijn betoog geven (zie Figuur 1). Uit de titel van mijn oratie zal het $u$ duidelijk zijn dat ik een onderscheid maak tussen drie niveaus van analyse van de activiteiten van accountants, te weten de markt, het kantoor en het controleproces. Voor elk van de drie niveaus zal ik eerst kort ingaan op de economische analyse van activiteiten van accountants in het algemeen. Vervolgens zal ik die economische analyse illustreren aan de hand van een specifiek onderwerp. Daarbij maak ik zoveel mogelijk gebruik van empirische gegevens.

Als specifiek onderwerp op het niveau van de markt heb ik gekozen voor toetreding. Bij de behandeling van dit onderwerp zal ik gegevens gebruiken over de toetreding van nieuwe accountants en accountantskantoren tot de Nederlandse markt voor accountantscontrole. Daarbij zal ik vooral aandacht schenken aan de effecten van de wet van 1993 waardoor een deel van de Accountants-Administratieconsulenten (AA's) controlebevoegd is geworden. Als specifiek onderwerp op het niveau van het kantoor heb ik gekozen voor de bij accountantskantoren gangbare wijze van partnerselectie, het 'up-orout' systeem. Met behulp van gegevens over de carrières van Nederlandse accountants zal ik $u$ laten zien dat de term 'up-or-outplacement' een betere beschrijving geeft van het selectiesysteem. Als specifiek onderwerp op het niveau van het controleproces heb ik gekozen voor de accountantscontrole van kleinere cliënten. Daarbij zal ik onder andere gebruik maken van gegevens over rechtszaken tegen accountants en gegevens uit controledossiers van kleinere cliënten.

Twee belangrijke overeenkomsten verbinden de drie voorbeelden. Ten eerste maak ik in alle drie de voorbeelden zoveel moge- 


\section{Dominees op de markt}

lijk gebruik van empirische gegevens. Ten tweede wordt in alle drie de voorbeelden een economische invalshoek gekozen, oftewel het perspectief van de accountant als koopman. Het eerste voorbeeld gaat ervan uit dat accountants met elkaar concurreren op basis van de kwaliteit en prijs van de controle. Het tweede voorbeeld gaat ervan uit dat accountantskantoren een selectiesysteem toepassen waarmee ze zo goed mogelijk medewerkers kunnen aantrekken. Het laatste voorbeeld gaat ervan uit dat accountants controles efficiënt en effectief uitvoeren.

Figuur 1: $\quad$ Een economische analyse van de markt, het kantoor en het controleproces van accountants

\begin{tabular}{llll}
\hline Markt & Kantoor & Controleproces \\
$\begin{array}{l}\text { Specifiek } \\
\text { onderwerp }\end{array}$ & Toetreding & $\begin{array}{l}\text { Partner } \\
\text { selectie } \\
\text { ('up or out') }\end{array}$ & $\begin{array}{l}\text { Accountants- } \\
\text { controle in } \\
\text { het MKB }\end{array}$ \\
Gegevens & $\begin{array}{l}\text { Accountants } \\
\text { en kantoren } \\
\text { in Nederlandse } \\
\text { markt }\end{array}$ & $\begin{array}{l}\text { Carrières } \\
\text { accountants }\end{array}$ & Rechtszaken \\
& & Controledossiers \\
\hline
\end{tabular}

Voordat ik begin met mijn analyse van accountants wì ik u graag nog vertellen wat mij recent is overkomen. Het betreft een voorval dat mij duidelijk heeft gemaakt dat voor een jonge hoogleraar een kennismaking een onverwachte wending kan hebben. Op het jongstleden Maastrichtse Preuvenemint werd ik voorgesteld aan kennissen van mijn 
gezelschap. Nadat kort de diverse heerlijkheden van de Maastrichtse restaurateurs waren besproken werd mij de volgende vraag gesteld: "En, wat doe jij? Jij zit zeker bij de universiteit?". Het deed mij goed dat $z \mathrm{ij}$ dacht dat ik bij de universiteit werkte en met enige trots antwoordde ik "Ja". Die trots verdween snel na de volgende vraag: "Wat studeer je dan?". Om de vragenstelster en mijzelf niet in verlegenheid te brengen, heb ik daarop maar "Economie" gezegd. En op zich was dat nog niet eens zo heel erg gelogen. Net zoals een student moet ook een hoogleraar veel studeren.

\section{De markt}

\subsection{Economische analyse van de markt voor accountants- controle}

Van de drie te bespreken niveaus heeft de markt voor accountantscontrole het meest geprofiteerd van economische analyses. Een eerste verklaring daarvoor is dat voor economen een analyse op het niveau van de markt het meest voor de hand ligt. Daarnaast zijn gegevens over markten voor accountantscontrole redelijk goed beschikbaar. Empirische economische studies op dit gebied worden sinds het begin van de jaren tachtig in groeiende omvang gepubliceerd. De structuur van markten voor accountantscontrole en de wijze waarop prijsvorming op deze markten tot stand komt zijn uitgebreid onderzocht in de beginjaren van dit onderzoek. Later zijn ook de effecten van wet- en regelgeving op deze markten onderzocht. Het gaat daarbij zowel om vraagregulering als om aanbodregulering. Voorbeelden daarvan zijn studies naar de effecten van een verplichte accountantscontrole en studies naar de effecten van toelatingseisen tot de 


\section{Dominees op de markt}

markt voor accountantscontrole. Zijn in het begin van dit gebied van onderzoek vooral markten in Angelsaksische landen onderzocht, sinds het einde van de tachtiger jaren worden ook markten in continentale Europese landen onderzocht. Ook de Nederlandse markt voor accountantscontrole is het onderwerp geweest van enkele empirische economische studies (zie bijvoorbeeld Buijink 1992; Langendijk 1994; en Maijoor 1994).

Anderen hebben reeds excellente overzichten gegeven van onderzoek naar markten voor accountantscontrole (zie bijvoorbeeld Yardley e.a. 1992; Moizer 1992; en Simunic en Stein 1995). Ik zal daarom snel overgaan tot het specifieke onderwerp toetreding. Wel wil ik graag nog opmerken dat dit terrein van onderzoek bruikbare resultaten heeft opgeleverd voor praktische vraagstukken ten aanzien van de wet- en regelgeving voor markten voor accountantscontrole. De resultaten van dit veld van onderzoek zijn bijvoorbeeld bruikbaar bij het vraagstuk ten aanzien van het creëren van een interne markt voor accountantscontrole in de Europese Unie. Dit onderwerp heeft een hoge prioriteit gekregen van de Europese Commissie en naar mijn verwachting zullen bij de hervorming van die markt resultaten van voorgaand onderzoek een belangrijke rol spelen.

\subsection{Toetreding}

In het afgelopen decennium zijn de structuur en dynamiek van de Nederlandse markt voor accountantscontrole belangrijk gewijzigd. Daarmee is de markt een stuk dichter gekomen bij de idealen van dereguleerders zoals Minister Wijers. Verklaringen voor de wijzigingen in de markt voor accountantscontrole hangen vooral sarnen met veranderingen in wet- en regelgeving. De belangrijkste daarvan is de 
Figuur 2: $\quad$ Totaal aantal accountants in het openbaar beroep

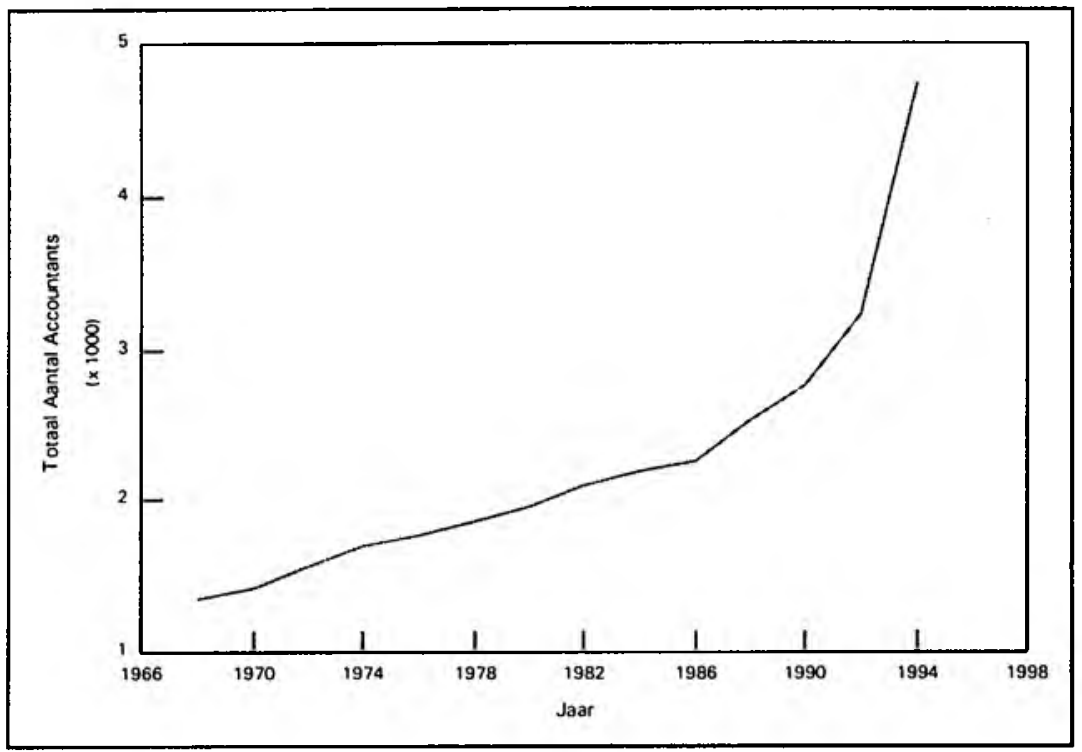

Bronnen: De gegevens betreffende AA's zijn direct door de NovAA beschikbaar gesteld. De gegevens betreffende RA's zijn gebaseerd op de NIVRA ledenlijsten. De gegevens gaan ervan uit dat alle AA's met controlebevoegdheid actief zijn in het openbaar beroep. Voor RA's zijn gedetailleerde gegevens direct beschikbaar over het aantal actieven in het openbaar beroep.

implementatie van de Achtste EEG-Richtlijn die de opleidingsmogelijkheden tot controlerend accountant heeft verruimd. Daardoor heeft sinds 1993 een deel van de AA's het recht verworven om, net zoals registeraccountants (RA's), controles uit te voeren. Sinds de invoering van de wet zijn ongeveer $1700 \mathrm{AA}$ 's toegetreden tot de markt voor 
accountantscontrole. Het betreft hier de markt voor wettelijk verplichte controles. De markt voor niet wettelijk verplichte controles is sinds 1993 geheel vrijgegeven.

Ik zal de wijzigingen in de Nederlandse markt illustreren met gegevens over toetreding zoals die heeft plaatsgevonden in recente jaren. De reden om naar toetreding te kijken is de volgende. De eerste studies op het gebied van competitie in markten voor accountantscontrole hebben vooral gekeken naar het niveau van concentratie. Latere studies hebben gesteld dat dynamische maatstaven zoals toetreding, uittreding en marktaandeelinstabiliteit betere indicatoren zijn van het niveau van competitie. Door toetreding van nieuwe kantoren krijgen cliënten meer keuze en verwacht kan worden dat bestaande kantoren hun cliënten trachten vast te houden door het verbeteren van de kwaliteit of door het verlagen van de prijs. Het empirisch onderzoek van bijvoorbeeld Copley en Doucet (1993) heeft een positieve relatie vastgesteld tussen competitie en controlekwaliteit en een negatieve relatie tussen competitie en de prijs van de controle.

Figuur 2 geeft een overzicht van het totaal aantal certificerende accountants in Nederland actief in het openbaar beroep. Het effect van de wetswijziging van 1993 is duidelijk zichtbaar. De groei in de periode 1992-1994 is ongeveer zeven keer zo groot als de gemiddelde groei in de voorafgaande perioden. Door de toetreding van AA's is de capaciteit aan de aanbodzijde van de markt in twee jaar met een kleine $50 \%$ gegroeid.

Hoewel gegevens over toetreding van individuele accountants een eerste indicatie geven van de wijzigingen in de markt, bieden gegevens over de toetreding, van kantoren een beter zicht op de wijzigingen in de structuur en dynamiek van een markt. Ik zal daartoe eerst enige gegevens laten zien met betrekking tot grote kantoren en vervolgens enige gegevens betreffende kleine kantoren. 
Tabel 1 geeft twee lijsten met de top-15 van accountantskantoren zoals die jaarlijks in de financiële pers verschijnen. De twee lijsten betreffen de jaren 1990 en 1993 en de kantoren zijn gerangschikt op basis van hun omzet in miljoenen guldens. In de regel werden in de periode vóór 1993 alleen typische RA-kantoren in dit soort lijsten opgenomen. Sinds 1993 worden vanwege de eerder genoemde wetgeving ook de typische AA-kantoren in deze lijsten opgenomen.

Tabel 1: Top-15 kantoren Nederlandse markt voor accountantsdiensten op basis van omzet in miljoenen guldens, 1990 en 1993

1990

1. Moret, Ernst \& Young

2. Coopers \& Lybrand

3. KPMG

4. Deloitte \& Touche

5. VB Accountants

6. BDO Camps Obers

7. Price Waterhouse

8. Arthur Andersen

9. Paardekoper \& Hoffman

10. Walgemoed

11. Berk

12. Foederer

13. Arenthals

14. Wallast

15. Joanknecht

1993

$\begin{array}{lll}649 & \text { Moret, Ernst \& Young } & 751 \\ 602 & \text { KPMG } & 703 \\ 578 & \text { Coopers \& Lybrand } & 686 \\ 420 & \text { Deloitte \& Touche } & 540 \\ 149 & \text { VB Accountants } & 239 \\ 102 & \text { BDO Camps Obers } & 137 \\ 81 & \text { Arthur Andersen } & 136 \\ 78 & \text { Price Waterhouse } & 104 \\ 70 & \text { Paardekoper \& Hoffman } & 91 \\ 65 & \text { ABABncb } & \mathbf{8 5} \\ 57 & \text { Berk } & 85 \\ 21 & \text { Walgemoed } & 85 \\ 19 & \text { GrBO } & \mathbf{7 2} \\ 16 & \text { LTB } & \mathbf{5 2} \\ 15 & \text { AVM } & \mathbf{4 4}\end{array}$

Bronnen: Het FD, De omzetcijfers van 1990 en De omzetcijfers van 1993 en het International Accounting Bulletin, Issue 101, October 1992. 


\section{Dominees op de markt}

De AA-kantoren zijn vetgedrukt opgenomen in de lijst van 1993. Zoals uit de tabel blijkt behoren vier typische AA-kantoren tot de top15 van de Nederlandse accountantskantoren in 1993. Daarmee lijkt de top-15 van de Nederlandse markt voor accountantscontrole belangrijk gewijzigd. Echter, de gegevens zijn enigszins onzuiver; zij zijn gebaseerd op de totale omzet en niet op de controle-omzet. De AAkantoren en RA-kantoren bedienen voor een deel andere markten en zullen daardoor een andere omzetverdeling kennen. De markt voor de controles van beursgenoteerde ondernemingen wordt bijvoorbeeld alleen bediend door de RA-kantoren. Daarnaast genereren de nieuwkomers in de top nog beperkt hun inkomsten uit controle-opdrachten. Echter, voor de nieuwkomers in de top zijn de barrières beperkt om op termijn meer controle-inkomsten te genereren. $\mathrm{Zij}$ hebben netwerken die belangrijke delen van het land afdekken en zijn in principe geschikte partners voor elkaar en voor internationale netwerken van accountantskantoren. Het eerste blijkt onder andere uit de huidige toenadering tussen de AA-kantoren GIBO en AccoN. De laatste is overigens geen top-15 kantoor. Als de twee kantoren fuseren zal het nieuwe kantoor terechtkomen in de top-8 met een omzet groter dan die van het kantoor Price Waterhouse (zie FEM, 24 juni 1995, blz. 35).

Niet alleen in het segment van de grotere kantoren maar ook in het segment van de kleinere kantoren is sprake van een toenemende dynamiek. Tabel 2 geeft een overzicht van de toetreding tot de Nederlandse markt voor accountantscontrole in de periode 1968-1992. De gehele periode is opgedeeld in tijdvakken van zes jaar. Gegevens voor de periode na 1992 zijn nog niet beschikbaar en derhalve is het effect van de toetreding van AA's vanaf 1993 nog niet meegenomen. De gegevens betreffen alle kantoren werkzaam op de Nederlandse controlemarkt. Als eerste valt op de netto-groei van het aantal accountantskantoren van 350 in 1968 tot 617 in 1992. De totale (bruto) toe- 


\section{Dominees op de markt}

treding per jaar is nog indrukwekkender, zeker in het meest recente tijdvak. Gemiddeld treden in die periode 65 accountantskantoren per jaar toe tot de markt. De laatste kolom van tabel 2 bevat gegevens over het gemiddelde marktaandeel per jaar van toetreders tot de markt voor accountantscontrole in Nederland. Dit marktaandeel stijgt over de gehele periode en komt in het laatste tijdvak uit op ongeveer $12 \%$ per jaar.

Tabel 2: Toetreding tot de Nederlandse markt voor accountantscontrole, 1968-1992

\begin{tabular}{|c|c|c|}
\hline $\begin{array}{l}\text { Totaal } \\
\text { aantal } \\
\text { kantoren }\end{array}$ & $\begin{array}{l}\text { Totaal aantal } \\
\text { toetreders } \\
\text { per jaar }\end{array}$ & $\begin{array}{l}\text { Totaal marktaandeel } \\
\text { van toetreders in jaar } \\
\text { van toetreding }\end{array}$ \\
\hline
\end{tabular}

$\begin{array}{llll}1968-73 & 350 & 13,5 & 4,8 \% \\ 1974-79 & 265 & 22,3 & 7,5 \% \\ 1980-85 & 307 & 34,0 & 9,2 \% \\ 1986-91 & 413 & 65,0 & 12,3 \% \\ 1992 & 617 & & \end{array}$

Bron: Buijink en Maijoor (1993).

De gepresenteerde gegevens bevestigen dat in het afgelopen decennium de structuur en dynamiek van de markt voor accountantscontrole belangrijk zijn gewijzigd. Vier verklaringen, die vooral samenhangen met veranderingen in (Europese) wet- en regelgeving, kunnen voor de geschetste veranderingen worden gegeven. De meest evidente verklaring is al eerder genoemd. Door de implementatie in Nederland 


\section{Dominees op de markt}

van de Achtste EEG-Richtlijn zijn de opleidingsmogelijkheden tot accountant verruimd en is een deel van de AA's de mogelijkheid geboden om de controlebevoegdheid te verwerven. Ten tweede is het aantal cliënten aan de vraagzijde van de markt gegroeid. Die groei heeft vooral plaatsgevonden in het segment van de kleinere cliënten. Tengevolge van de implementatie van de Vierde EEG-Richtlijn in Nederland zijn middelgrote ondernemingen tot een jaarlijkse accountantscontrole verplicht. Deze cliënten kunnen uitstekend worden bediend door kleinere accountantskantoren. Ten derde heeft de versoepeling in 1987 van de beroepsregel met betrekking tot reclame er wellicht voor gezorgd dat de kansen op succes voor toetreders zijn verhoogd ${ }^{2}$. Reclame maken is immers onmisbaar voor toetreders om potentiële cliënten bekend te maken met hun diensten.

Tot slot kan een complementaire verklaring worden gegeven voor de groei aan de onderkant van de markt die niet zozeer samenhangt met veranderingen in wet- en regelgeving. Het continue proces in de afgelopen twee decennia van fusies en overnames aan de bovenkant van de markt heeft de carrièremogelijkheden voor accountants bij de grotere kantoren aanzienlijk veranderd. Grotere kantoren hebben in het algemeen een lage ratio tussen het aantal partners en het aantal medewerkers. Door de groei van de grote kantoren zijn de kansen voor een medewerker op het partnerschap bij een groot kantoor verlaagd. Hierdoor is de optie om zelfstandig aan de slag te gaan aantrekkelijker geworden.

Ter illustratie van de laatste verklaring is in tabel 3 een onderscheid gemaakt naar de wijze waarop toetreding tot stand is gekomen. Een kantoor ,kan worden opgezet door accountants

${ }^{2}$ Onder bepaalde condities kan reclame het juist lastiger maken om toe te treden tot een markt. 


\section{Dominees op de markt}

afkomstig van bestaande kantoren, door accountants van buiten het openbaar beroep, of door accountants die net hun kwalificatie als accountant hebben behaald.

Tabel 3: Wijze van toetreding van kantoren tot de Nederlandse markt voor accountantscontrole, 1968-1992

\begin{tabular}{llll}
\hline & $\begin{array}{l}\text { Marktaandeel } \\
\text { toetreders } \\
\text { bestaande kantoren }\end{array}$ & $\begin{array}{l}\text { Marktaandeel } \\
\text { uittoetreders } \\
\text { bedrijfslevenna }\end{array}$ & $\begin{array}{l}\text { Marktaandeel } \\
\text { uittoetreders direct } \\
\text { kwalificatie }\end{array}$ \\
$1968-73$ & $1,9 \%$ & $0,6 \%$ & $2,3 \%$ \\
$1974-79$ & $4,0 \%$ & $1,0 \%$ & $2,5 \%$ \\
$1980-85$ & $4,4 \%$ & $1,5 \%$ & $3,3 \%$ \\
$1986-92$ & $5,4 \%$ & $2,2 \%$ & $4,7 \%$ \\
\hline
\end{tabular}

Bron: Buijink en Maijoor (1993).

Gedurende de gehele periode 1968-1992 hebben toetredende accountants afkomstig van bestaande kantoren het grootste marktaandeel. Dit is in overeenstemming met de gedachte dat het fusieproces aan de bovenkant van de markt de groei van de onderkant van de markt heeft gevoed. Dit heeft bijgedragen aan het ontstaan van een duale marktstructuur: een klein aantal grote kantoren en een groot aantal kleine kantoren. Tevens is door fusies en overnames voor medewerkers bij het grote accountantskantoor het zelfstandig ondernemerschap een aantrekkelijke optie geworden. Het interessante van deze laatste verklaring is dat zij een verband legt tussen de structuur van de markt voor accountantsdiensten en de carrières van medewerkers binnen accoun- 
tantskantoren. Daarmee brengt deze laatste verklaring mij bij het tweede deel van mijn oratie: de economische analyse van het accountantskantoor.

\section{Het accountantskantoor}

\subsection{Economische analyse van het accountantskantoor}

De meeste accountants werken niet alleen. Als accountants gaan samenwerken in een kantoor dienen veel zaken te worden geregeld. Welke rechts- en organisatievorm wordt gekozen, hoe worden opbrengsten en risico's gedeeld, hoe worden partners beoordeeld, hoe worden nieuwe partners tot het kantoor toegelaten en hoe wordt het kantorennetwerk uitgebreid bij eventueel succes?

De economische analyse van accountantskantoren is nog nauwelijks ontwikkeld. Een belangrijke oorzaak daarvan is waarschijnlijk het gebrek aan systematische gegevens over de organisatie van accountantskantoren. Het feit dat nauwelijks onderzoeksresultaten beschikbaar zijn wil niet zeggen dat er in de praktijk geen problemen zijn op dit gebied. Zeer recent werden in de financiële pers de veranderingen van rechtsvorm van accountantskantoren gemeld. Die veranderingen hingen vooral samen met problemen ten aanzien van beroepsaansprakelijkheid. Ook is een aantal berichten verschenen dat erop wijst dat de maatschap een beknellende organisatievorm is voor het moderne accountantskantoor.

Ik zal een tweetal voorbeelden van verder onderzoek geven. Het eerste voorbeeld betreft de fusie- en overname-strategieën van accountantskantoren. Hoewel fusies aan de bovenkant van de markt in de nabije toekomst niet waarschijnlijk zijn, blijft dit onderwerp 
relevant. De onstuimige groei aan de onderkant van de markt, zoals gedocumenteerd in de voorgaande sectie, heeft gezorgd voor een nieuw reservoir van kandidaten voor overname. Verwacht kan worden dat de grote kantoren verschillen in hun belangstelling voor deze kandidaten. Tussen kantoren zijn namelijk duidelijke verschillen te ontdekken in de wijze waarop zij trachten te groeien. Sommige kantoren trachten te groeien door overnames, andere kantoren trachten uit te breiden door middel van interne groei. In Nederland zijn Arthur Andersen en Price Waterhouse de typische voorbeelden van de laatste strategie. Interessant zou zijn om te onderzoeken wat de effecten zijn van de verschillende groeistrategieën op het succes van accountantskantoren.

$\mathrm{Bij}$ het onderzoek naar fusies en overnames dient ook gekeken te worden naar de vorming van internationale kantoren. De huidige internationale kantoren zijn feitelijk netwerken van nationale kantoren waarbij de laatsten een grote mate van autonomie hebben behouden. Door de grote autonomie van de nationale kantoren is het lastig om tot collectieve afspraken te komen en bestaan risico's dat nationale kantoren uit het netwerk stappen. Verwacht kan worden dat dit leidt tot onderinvestering in het netwerk. De huidige structuur van internationale kantoren lijkt het gevolg te zijn van nationale wet- en regelgeving met betrekking tot het management en eigendom van accountantskantoren. Deze wet- en regelgeving beperkt de mogelijkheden om nationale kantoren te integreren door middel van wederzijdse participaties in het management en eigendom. Interessant zou zijn om te onderzoeken of wet- en regelgeving daadwerkelijk beknellend is en of zij daarmee de internationale activiteiten van accountants beperkt.

Het tweede voorbeeld van verder onderzoek is tegelijkertijd het onderwerp dat ik als speciaal voorbeeld heb gekozen van een 


\section{Dominees op de markt}

economische analyse op het niveau van het accountantskantoor. Het onderwerp betreft het partnerselectiesysteem van accountantskantoren.

\subsection{Partnerselectie ('up-or-out')}

De typische wijze van partnerselectie die door accountantskantoren wordt toegepast is het 'up-or-out' systeem. Dit selectiesysteem laat jonge carrièremakers aan den lijve ondervinden dat stilstand achteruitgang is. 'Up-or-out' selectie komt erop neer dat op meerdere momenten gedurende zijn carrière de medewerker wordt geëvalueerd voor zijn geschiktheid op een hogere functie. Is de medewerker geschikt voor een hogere functie, dan zal promotie plaatsvinden. Is de medewerker niet geschikt voor een hogere functie, dan moet deze zijn huidige functie staken. Een ander belangrijk element van het selectiesysteem is dat de ladder van functies op weg naar het partnerschap binnen een redelijk vaste periode moet worden beklommen. De laatste en belangrijkste 'up-or-out' beslissing, de beslissing over toelating tot het partnerschap, vindt meestal plaats vóór het 40ste levensjaar. Twee gevolgen van het 'up-or-out' systeem zijn dat partners hoofzakelijk intern worden gerecruteerd en dat oudere accountants die geen partner zijn een kleine groep vormen binnen accountantskantoren.

Voor Nederlandse accountantskantoren zijn gedetailleerde gegevens beschikbaar over de carrières van accountants. Om betrouwbare gegevens te verkrijgen over de selectie van partners dienen de carrières van accountants over lange tijd te worden gevolgd. De volgende gegevens zijn gebaseerd op de complete cohorten van accountants die in de periode 1972-1978 hun kwalificatie als accountant hebben behaald. Hun carrières zijn gevolgd tot en met het jaar 1992. Op tenminste negen momenten in hun carrière is gekeken 


\section{Dominees op de markt}

bij welk kantoor zij werkzaam zijn. Van de totale populatie bleken 401 accountants ten tijde van kwalificatie bij een groot accountantskantoor te werken. Veertien jaar na kwalificatie is deze groep geslonken tot 220 accountants werkzaam bij een groot accountantskantoor.

In totaal zijn 190 accountants partner geworden bij een groot accountantskantoor. Tabel 4 geeft een overzicht van het aantal medewerkers dat extern werd aangetrokken voor het partnerschap. Uit de gegevens blijkt dat de grote accountantskantoren nauwelijks werven bij andere accountantskantoren. Meer dan $75 \%$ van de accountants die partner zijn geworden bij een groot kantoor werkten bij datzelfde kantoor ten tijde van het behalen van hun kwalificatie als accountant.

Tabel 4: Accountants van de cohorten 1972-1978 die partner zijn geworden bij de grote Nederlandse accountantskantoren

Carrière gestart als medewerker bij hetzelfde kantoor

Carrière gestart als medewerker bij een ander kantoor

Carrière gestart buiten het openbaar beroep

Totaal aantal medewerkers dat partner is geworden bij de grote accountantskantoren

Bron: Maijoor en Meuwissen (1993)

Slechts 6\% van de partners werkte bij een ander kantoor ten tijde van kwalificatie. Bij de extern geworven partners is de relatief hoge bijdrage van accountants van buiten het openbaar beroep opvallend. 
Dit hangt ten dele samen met de overname van interne accountantsdiensten van ondernemingen door de grote accountantskantoren.

De zojuist gepresenteerde gegevens zijn in overeenstemming met de toepassing van het 'up-or-out' systeem door Nederlandse accountantskantoren. Vanuit economisch perspectief lijkt het 'up-orout system' niet logisch. Immers, een medewerker die niet geschikt is voor een hogere functie, wordt gedwongen om zijn huidige functie te staken. Eén van de gevolgen van het selectiesysteem kan dus zijn dat een medewerker die goed functioneert in zijn huidige functie gedwongen wordt te vertrekken. Voor zowel de medewerker als het accountantskantoor lijkt dit systeem nadelig. De medewerker heeft gedurende zijn carrière bij het kantoor veel kennis opgebouwd die specifiek is voor het kantoor en haar cliënten. Die kennis zal voor een deel nutteloos zijn in een andere betrekking. Ook voor het kantoor lijkt het 'upor-out' systeem nadelig. De kennis van de medewerker is specifiek gericht op het kantoor en haar cliënten en gaat door het gedwongen ontslag veel menselijk kapitaal verloren. Dit kantoorspecifieke menselijk kapitaal zal weer moeten worden opgebouwd bij nieuwe, jonge medewerkers. Waarom passen accountantskantoren dit schijnbaar economisch onlogische systeem toe? Waarom komen het kantoor en de medewerker niet overeen dat zij een 'life-time' functie creëren op een niveau onder het partnerschap tegen een lagere vergoeding?

Om die vraag te beantwoorden is het waardevol om te kijken naar het economisch onderzoek dat reeds heeft plaatsgevonden met betrekking tot partnerselectie bij advocatenkantoren (zie bijvoorbeeld Gilson en Mnookin 1989). De gedachten die in dat onderzoek naar voren worden geschoven zijn de volgende. Bij de aanname van medewerkers hebben de zittende partners onzekerheid over de geschiktheid van de nieuwelingen voor het partnerschap. Er is niet alleen onzekerheid over hun vaktechnische kwaliteiten, maar vooral is er onzeker- 


\section{Dominees op de markt}

heid over hoe goed de nieuwe medewerkers zullen passen in het team van partners. Kantoren willen bij de aanname van nieuwe partners zeker zijn dat het goed gaat. Ontslag van een partner betekent niet alleen een verlies aan kantoorspecifiek menselijk kapitaal maar ook problemen verbonden aan het uitkopen van een mede-eigenaar. Het 'up-or-out' systeem biedt het kantoor goede mogelijkheden om de geschiktheid van een medewerker voor het partnerschap te beoordelen. Over een langere periode kan worden bezien of een medewerker voldoende vaktechnische kwaliteiten heeft en of hij past binnen het team van partners. Het is evident dat de risico's van een mislukking beduidend kleiner zijn dan wanneer partners direct van buiten het kantoor zouden worden aangetrokken.

De risico's voor de medewerkers zijn van een andere aard. $\mathrm{Zij}$ lopen vooral risico's als zij geschikt blijken te zijn voor het partnerschap. Door bij een kantoor te gaan werken beslist de jonge medewerker om een belangrijk deel van zijn menselijk kapitaal op te bouwen specifiek gericht op dat kantoor en haar cliënten. Daarmee kan de goed functionerende medewerker na verloop van tijd in een lastig parket komen. De bestaande partners zouden de neiging kunnen hebben om de beslissing tot promotie tot het partnerschap zo lang mogelijk uit te stellen. Immers, de goede medewerker verhoogt de netto-opbrengsten van het kantoor en door uitstel van promotie hoeven de bestaande partners de opbrengsten niet met één persoon meer te delen. Dreigen met vertrek door de medewerker als de bevordering tot partnerschap wordt uitgesteld is lastig. De reden is dat zijn menselijk kapitaal beduidend minder waard is in een functie buiten het kantoor.

Het 'up-or-out' systeem is een oplossing voor de zojuist geschetste problemen van de medewerker. Door het 'up-or-out' systeem wordt het onmogelijk gemaakt dat de partnerbeslissing wordt uitgesteld. Het 'up-or-out' systeem is een impliciet contract met de 
afspraak dat de ladder van functies op weg naar het partnerschap binnen een bepaalde periode zal worden afgelegd. Met andere woorden, het 'up-or-out' systeem is een belofte van het kantoor om tijdig kleur te bekennen over de geschiktheid van een medewerker voor het partnerschap. Dit is van groot belang voor de goede medewerker die zich met zijn menselijk kapitaal voor een belangrijk deel aan het kantoor heeft gebonden.

Het laatste belangrijke element van het selectiesysteem is dat 'up-or-out' voor beide partijen toch niet zo kostbaar is als het lijkt in het geval van het ontslag van een goede medewerker. De medewerker die geen toegang krijgt tot het partnerschap kan geplaatst worden in een betrekking waarbij zowel de medewerker als het kantoor beperkte nadelen ondervinden van de beëindiging van de carrière binnen het kantoor. Daarbij kan gedacht worden aan plaatsing van de medewerker bij een cliënt of bij een ander onderdeel binnen het kantoor. In beide gevallen kan het specifiek op het kantoor en haar cliënten gerichte menselijk kapitaal nog gebruikt worden. De suggestie is dan ook niet dat het 'up-or-out' is, maar 'up-or-outplacement'. Door outplacement van een medewerker bij een cliënt wordt de schade van de negatieve uitkomst van de selectie voor zowel de medewerker als het kantoor beperkt. Door de medewerker bij een cliënt te plaatsen kan de medewerker profiteren van een deel van zijn opgebouwde cliëntspecifieke kennis. Voor het kantoor betekent plaatsing bij een cliënt een versteviging van het cliëntennetwerk.

Om te onderzoeken of de 'up-or-outplacement' hypothese ook geldt voor Nederlandse accountants zijn uit de eerder genoemde totale groep van accountants de medewerkers geselecteerd met een typische 'up-or-out' carrière met een negatieve uitkomst ten aanzien van het partnerschap. Als criterium is gebruikt dat de accountant werkzaam bij een groot kantoor na het behalen van zijn kwalificatie als accountant 
meer dan zes jaar bij dat kantoor in dienst is geweest. Vervolgens is hij vertrokken zonder partner te zijn geworden. In totaal bleken 41 accountants in dit carrièrepatroon te passen. Voor die 41 accountants is onderzocht welke functie zij hebben aanvaard na hun vertrek bij het accountantskantoor. Van de 41 accountants bleken 18 een betrekking bij een cliënt te hebben aanvaard. Vier accountants kregen een betrekking in de management consulting binnen het kantoor. In totaal 11 accountants vertrokken naar een onderneming die geen cliënt was van het kantoor. In acht gevallen kon niet worden vastgesteld of de desbetreffende organisatie wel of geen cliënt was van het accountantskantoor. Deze en de eerder gepresenteerde resultaten bevestigen in grote lijnen dat de grote accountantskantoren, net zoals advocatenkantoren, een 'up-or-outplacement' selectie-systeem toepassen.

\section{Het controleproces}

\subsection{Economische analyse van het controleproces}

Het controleproces van accountants betreft het geheel aan activiteiten dat accountants ondernemen om tot een oordeel te komen over de getrouwheid van een financiële verantwoording. Dat oordeel wordt vastgelegd in de accountantsverklaring. Hoewel buitenstaanders misschien de indruk hebben dat dit een tamelijk mechanistisch proces is dat volgens vaste procedures verloopt, is dit geenszins het geval. Het controleren van een jaarrekening is niet een kwestie van systematisch de bonnen nalopen. Zoals Dassen (1995) heeft gesteld dat creatief boekhouden een pleonasme is, geldt hetzelfde voor de uitdrukking creatief controleren. Op vele momenten in de controle maken accountants subjectieve afwegingen. $\mathrm{Zij}$ beperken daarbij bewust de omvang 
van de controle, waardoor een beperkt risico bestaat dat de goedgekeurde financiële verantwoording een materiële fout bevat. Economisch gezien is dit uitstekend verdedigbaar. Of het nu gaat om het examineren van de kennis van studenten, of het controleren van de snelheid van weggebruikers, bijna alle controles zijn gebaseerd op steekproeven. Controles die alle fouten zouden moeten onderscheppen zijn simpelweg te kostbaar.

Het accountantscontroleproces is het onderwerp geweest van vele empirische studies. De meeste van deze empirische studies hebben een gedragsmatige invalshoek. Die nadruk op de gedragsmatige kant van het controleproces is logisch omdat vooral de individuele oordeelsvorming van accountants werd onderzocht. Daarbij werd veel gebruik gemaakt van de uit de psychologie afkomstige techniek van laboratoriumexperimenten. Pas sinds kort zijn empirische studies verschenen die impliciet of expliciet een economische invalshoek toepassen om het controleproces van accountants te analyseren. Om het controleproces te verklaren wordt veel nadruk gelegd op de economische context waarin de controle wordt uitgevoerd. Verder wordt veelal gebruik gemaakt van gegevens over werkelijk uitgevoerde controles. Het onderzoek tracht het controleproces te analyseren vanuit het perspectief dat accountants deze zo efficiënt en effectief mogelijk zullen uitvoeren. Bij de uitvoering van de controle zal de accountant rekening houden met: (1) de apriori kans dat een fout zich in een financiële verantwoording bevindt, (2) de efficiëntie en effectiviteit van de diverse controlemiddelen voor een gegeven cliënt, en (3) de kans dat een fout in de jaarrekening leidt tot repercussies tegen de accountant. Ik zal kort een aantal voorbeelden geven van recent onderzoek op dit terrein.

Een aantal onderzoeken heeft getracht de uitgebreidheid van werkzaamheden van accountants te verklaren aan de hand van ken- 
merken van de cliënt. O'Keefe e.a. (1994) hebben voor een steekproefomvang van 249 cliënten getracht de uitgebreidheid van de werkzaamheden van de accountants te verklaren. Het aantal uren benodigd voor de controle hing samen met de grootte, complexiteit en risico van de cliënt. Een aantal andere onderzoeken heeft getracht veranderingen in de uitgebreidheid van de werkzaamheden van de accountant te verklaren aan de hand van wijzigingen in het risico van de cliënt. Om het simpel te zeggen, als een cliënt risicovoller wordt zal de accountant meer werk gaan verrichten. Voorbeelden van dit onderzoek zijn Bedard (1989), Mock en Wright (1993) en Quadackers e.a. (te verschijnen). Een aantal onderzoeken heeft getracht de mix van activiteiten van accountants voor een controle te verklaren. Davidson en Gist (te verschijnen) hebben onderzoek gedaan naar de relatie tussen planningsuren en de totale uren besteed aan de controle. De gedachte is dat hoe meer je aan de planning van een controle doet, hoe minder uitgebreid de controle zelf hoeft te zijn. Voor een steekproef van 75 controles werd deze relatie bevestigd. DiPietro e.a. (1995) hebben gekeken hoe de mix van controle-activiteiten van de accountant samenhangt met de sector waarin de cliënt werkzaam is.

De hier geciteerde onderzoeken zijn slechts het begin van een veld van onderzoek dat zich naar verwachting snel zal ontwikkelen. Een onderwerp dat speciale aandacht verdient is de relatie tussen de gebruikers van jaarrekeningen en de wijzen waarop de accountantscontrole wordt uitgevoerd. Wallage (1993) heeft gesuggereerd dat internationale verschillen tussen de wijzen van controleren samenhangt met verschillen in gebruikersgroepen. De reden is dat verwacht kan worden dat gebruikers van jaarrekeningen verschillen in hun preferenties ten aanzien van het voorkomen van verschillende typen fouten in de jaarrekening. Een bankier zal het uitermate belangrijk vinden dat de in de balans gepresenteerde activa niet zijn overschat en dat de 
gepresenteerde schulden niet zijn onderschat. Aandeelhouders zullen het meeste belang hechten aan een goede weergave van de winst. Derhalve kan verwacht worden dat indien bij een specifieke cliënt bankiers de belangrijkste gebruikersgroep vormen, de accountant vooral zal controleren op de juistheid van de activa en de volledigheid van de schulden. Indien bij een cliënt vooral de aandeelhouders de belangrijkste gebruikersgroep vormen, dan zal de accountant vooral op de juistheid en volledigheid van de winst moeten controleren. De verschillen in gebruikersgroepen worden dus gereflecteerd in de wijze van controleren door de acountant. Deze gedachte heeft een belangrijke rol gespeeld bij recente ontwikkelingen rond de accountantscontrole in het midden- en kleinbedrijf in Nederland.

\subsection{Accountantscontrole in het midden- en kleinbedrijf}

In 1994 heeft het MARC een controleprogramma ontwikkeld specifiek ten behoeve van de controle van cliënten in het midden- en kleinbedrijf. Dit programma is terechtgekomen in Leidraad 5 van de NOvAA. De behoefte aan dit vaktechnisch produkt kan deels worden verklaard door de sterk toegenomen vraag door kleinere cliënten. Ik wil het controleprogramma vandaag graag aanhalen omdat zij illustreert op welke wijze economische analyses behulpzaam kunnen zijn bij het maken van vaktechnische produkten voor de accountantscontrole.

Eerst zal ik u uitleggen wat de specifieke problemen zijn bij de controle van kleinere cliënten. Een accountant die een controle uitvoert dient uiteindelijk een uitspraak te doen over de getrouwheid van de jaarrekening. Hij zal zich daarvoor een beeld moeten vormen van zowel de juistheid als de volledigheid van de in de jaarrekening 
gepresenteerde gegevens. De juistheid betreft bijvoorbeeld bij de post voorraden of alle in de jaarrekening opgenomen voorraden ook daadwerkelijk bestaan. De volledigheid betreft bij deze post of alle bestaande voorraden ook daadwerkelijk in de jaarrekening zijn opgenomen. Het realiseren van de controledoelstelling juistheid is vrij eenvoudig. De accountant kan zich daarbij baseren op de door de cliënt aangeleverde gegevens. Het realiseren van de controledoelstelling volledigheid is lastig omdat het de controle betreft van gegevens die niet zijn gerapporteerd door de cliënt. Daarbij kan vooral worden gewezen op het risico van een niet volledige weergave van de opbrengsten of winsten doordat bepaalde verkopen niet of onjuist worden geregistreerd. Of, in populaire termen, het risico van het bestaan van "een winkeltje binnen de winkel". Voor de vaststelling van de volledigheid van gepresenteerde gegevens is het volgens de traditionele Nederlandse controleleer van belang dat de cliënt over een goede interne controle beschikt. Alleen een goede interne controle zou de accountant voldoende basis kunnen bieden om achteraf te controleren of de cliënt alles heeft gerapporteerd. Kleine ondernemingen hebben vaak een zwakke interne controle omdat zij een beperkte scheiding van functies kunnen aanbrengen. Derhalve dienen accountants volgens de traditionele Nederlandse controleleer in verhoudingsgewijs veel gevallen bij kleinere ondernemingen geen goedkeurende verklaring te geven.

Terzijde kan worden opgemerkt dat volledigheid niet alleen een probleem is bij kleine organisaties. Een voorbeeld daarvan is de verslaggeving van universiteiten. Zoals u waarschijnlijk wel weet hebben de Nederlandse universiteiten in de afgelopen tijd negatief in het nieuws gestaan omdat zij maar niet in staat zijn om hun financiële verslaggeving goed op orde te krijgen. Vooral zijn er problemen met de opbrengsten van het werken voor derden door universitair perso- 
neel. Het betreft hier onder andere het bekende bijklussen van professoren. Vaak zijn deze opbrengsten niet zichtbaar in de financiële verantwoordingen van universiteiten. Hun omvang is door de accountant lastig achteraf te controleren omdat voor de produktie van onderwijs en onderzoek nauwelijks andere produktiefactoren nodig zijn dan de inzet van de professor zelf. Daarmee kan de accountant achteraf geen houvast krijgen op basis van goederenstromen zoals dat gebeurt bij de controles van produktiebedrijven. Ook tijdschrijven door professoren zal de accountant weinig houvast bieden. De output per tijdseenheid varieert sterk per professor en ik vermoed dat hetzelfde geldt voor de totale tijd die professoren werken. Het probleem met betrekking tot de volledigheid van opbrengsten bij universiteiten zou alleen kunnen worden opgelost als een accountant continu aan de zijde van de professor zou meelopen. Dit lijkt mij voor beiden geen aangename oplossing, bovendien is zij zeer kostbaar.

Laten we teruggaan naar het voorbeeld van de controle in het midden- en kleinbedrijf. Vanuit economisch perspectief stoelt de door de traditionele Nederlandse controleleer voorgestelde terughoudendheid bij de controle van kleinere ondernemingen impliciet op de volgende twee veronderstellingen. De eerste veronderstelling is dat er substantiële risico's zijn dat ondernemers van kleinere ondernemingen delen van de opbrengst verzwijgen. De tweede veronderstelling is dat gebruikers van jaarrekeningen in dit segment veel belang hechten aan de volledigheid van de gepresenteerde opbrengsten. Immers, het risico van claims op dit gebied tegen de accountant zal direct afhangen van het belang dat door gebruikers wordt gehecht aan de volledigheid van de opbrengsten. De beantwoording van de vraag of de beide veronderstellingen juist zijn is een empirische kwestie. Daarom zal ik u nu enige resultaten van empirisch onderzoek geven die relevant zijn voor het beoordelen van de juistheid van de twee veronderstellingen. 


\section{Dominees op de markt}

De eerste resultaten betreffen rechtszaken tegen accountants aangespannen door gebruikers van jaarrekeningen. Gegevens over rechtszaken tegen accountants zijn niet makkelijk te krijgen. Het vermoeden is dat een deel van de conflicten tussen belanghebbenden en accountants onderling wordt geschikt zonder dat de rechter wordt ingeschakeld. Wat betreft het buitenlands onderzoek is de studie van St. Pierre en Anderson (1984) interessant. Zij onderzochten 129 gevallen waarin accountants in de Verenigde Staten aansprakelijk werden gesteld door belanghebbenden. De 129 gevallen betroffen cliënten variërend van benzinestations en meubelwinkels tot grote beursgenoteerde banken. Eén van de conclusies van St. Pierre en Anderson (1984) is dat problemen met aansprakelijkheid vooral komen door overschatting van activa en opbrengsten en het ten onrechte activeren van uitgaven. Geen van de cases had betrekking op de onderschatting van activa, of de onderschatting van opbrengsten. Verder bleek dat accountants vooral risico's lopen bij grote beursgenoteerde ondernemingen. Eén verklaring die daarvoor wordt gegeven is de veelheid en verscheidenheid van de belanghebbenden bij de jaarrekening van beursgenoteerde ondernemingen.

Ook voor Nederland zijn gegevens beschikbaar over claims tegen de accountant, zij het dat het een klein aantal gevallen betreft. Langendijk (1994) komt op een totaal van tien gepubliceerde civiele zaken in de afgelopen twee decennia. Uit zijn gegevens blijkt dat accountants vooral in problemen komen door waarderingsproblemen met betrekking tot posten in de jaarrekening. Wieleman en Kuijpers (1990) rapporteren de resultaten van interviews gehouden met Nederlandse assurantie-intermediairs die worden ingeschakeld in verband met verzekeringen voor accountants voor beroepsaansprakelijkheid. Hun bondige resultaten van deze interviews bevestigen dat accountants vooral in problemen komen op het terrein van waardering. Daarnaast 


\section{Dominees op de markt}

komen accountants in problemen doordat zij de controle onzorgvuldig uitvoeren of niet voldoende objectief zijn. Geen specifieke melding wordt gemaakt van enige claims in verband met de oncontroleerbaarheid van kleinere cliënten en de onderschatting van opbrengsten of winsten.

Dat ook bij de uitvoering van de controle de doelstelling volledigheid bij kleinere cliënten beperkte problemen oplevert moge blijken uit de volgende gegevens. Zij zijn ontleend aan de gedetailleerde controledossiers van 35 cliënten van een Nederlands accountantskantoor ${ }^{3}$. Geen van de cliënten in de steekproef is beursgenoteerd en ongeveer de helft van de cliënten is klein of middelgroot volgens de wettelijke criteria. Eénderde deel van de cliënten heeft 50 of minder werknemers. De gegevens hebben betrekking op de controle van de posten voorraden en kostprijs verkopen over een periode van twee jaar. Opgemerkt dient te worden dat problemen met betrekking tot volledigheid vooral tot uitdrukking zullen komen bij de controle van de post opbrengst verkopen. Echter, bij een consistente controle zullen problemen met betrekking tot volledigheid bij de opbrengsten ook resulteren in problemen met betrekking tot de volledigheid van de kostprijs verkopen. Gedurende de planning van een controle van een cliënt maken accountants een inschatting van factoren die een indicatie geven van het risico op materiële fouten in de jaarrekening. Deze reeks van factoren wordt per cliënt aan de hand van een checklist ingeschat. Tabel 5 geeft een overzicht van de gemiddelde gewichten die door de accountants aan in totaal 20 risicofactoren werden toegekend voor de 35 cliënten over twee jaren. Alleen de scores voor de top-vijf risicofactoren zijn gegeven en de score voor risico's

${ }^{3}$ Graag wil ik het accountantskantoor Deloitte \& Touche danken voor het beschikbaar stellen van gegevens. 


\section{Dominees op de markt}

samenhangend met de scheiding van functies bij de cliënt. Zoals eerder gezegd leidt een beperkte scheiding van functies tot problemen met betrekking tot volledigheid. Uit de tabel blijkt dat de risico's van de cliënten gerelateerd aan functiescheiding gemiddeld laag worden ingeschat en slechts een 16de plaats innemen.

Tabel 5: Risicofactoren gerangschikt naar gemiddelde score (schaal 1-5)

\begin{tabular}{lcc}
\hline Factor & Rang & Gemiddelde \\
\hline Winstgevendheid t.o.v. industrie & 1 & 3,25 \\
Macro-economische factoren & 2 & 2,59 \\
Kennisniveau van het administratief personeel & 3 & 2,39 \\
Risicohouding van het management & 4 & 2,38 \\
Informatietechnologie & 5 & 2,34 \\
Controletechnische functiescheiding & 16 & 1,71 \\
\hline
\end{tabular}

Bron: Quadackers en Maijoor (1995)

Tabel 6 geeft een overzicht van de door de accountants erkende risico's voor de verschillende controledoelstellingen met betrekking tot de post kostprijs verkopen. Een hoger risico wordt aangegeven door middel van een één. Uit de tabel blijkt dat bij de kostprijs verkopen de volledigheid in 11 gevallen een hoger risico opleverde. Verreweg de meeste risico's met betrekking tot de kostprijs verkopen werden onderkend met betrekking tot de doelstellingen bestaan en periodetoerekening. Bij de controle met betrekking tot de doelstelling volledig- 


\section{Dominees op de markt}

heid werd in $62 \%$ van de gevallen gesteund op de interne controle. Van de 35 cliënten kregen drie geen goedkeurende verklaring. Alle drie vielen in de categorie klein of middelgroot. Echter, voor alle drie de gevallen geldt dat de redenen voor het niet afgeven van een goedkeurende verklaring niet gerelateerd waren aan problemen met betrekking tot volledigheid.

Tabel 6: Risico-inschattingen per controledoelstelling voor de post kostprijs verkopen

\begin{tabular}{lccc}
\hline & 0 & 1 & $\mathrm{n}$ \\
\hline Volledigheid & 57 & 11 & 68 \\
Bestaan & 54 & 14 & 68 \\
Accuratesse & 57 & 11 & 68 \\
Periodetoerekening & 51 & 17 & 68 \\
Waardering & 51 & 9 & 60 \\
Presentatie & 66 & 0 & 66 \\
\hline Totaal & 336 & 62 & 398 \\
\hline
\end{tabular}

Bron: Quadackers en Maijoor (1995)

Deze resultaten van de controledossiers, en de eerder gepresenteerde resultaten met betrekking tot aansprakelijkheid, illustereren dat accountants bij kleinere ondernemingen beperkte problemen ondervinden met betrekking tot de volledigheid van de opbrengsten. Echter, het is van belang om te benadrukken dat de gepresenteerde resultaten 


\section{Dominees op de markt}

niet suggereren dat de accountant onvoorzichtig kan zijn met betrekking tot de controledoelstelling volledigheid. Indien vanwege een zwakke interne controle er geen zekerheid is over de volledigheid dient de accountant een zorgvuldige inschatting te maken van de kans op een materiële fout die niet wordt ontdekt. Hij kan op die inschatting steunen omdat, geheel in overeenstemming met de risico-analyse, het niet hebben van volledige zekerheid geen reden is voor het niet afgeven van een goedkeurende verklaring. $\mathrm{Bij}$ de inschatting van het risico met betrekking tot volledig Gedurende de planning van een controle van een cliënt maken accountants een inschatting van factoren die een indicatie geven van het risico op materiële fouten in de jaarrekening. Deze reeks van factoren wordt per cliënt aan de hand van een checklist ingeschat. Tabel 5 geeft een overzicht van de gemiddelde gewichten die door de accountants aan in totaal 20 risicofactoren werden toegekend voor de 35 cliënten over twee jaren. Alleen de scores voor de top-vijf risicofactoren zijn gegeven en de score voor risico's samenhangend met de scheiding van functies bij de cliënt. Zoals eerder gezegd leidt een beperkte scheiding van functies tot problemen met betrekking tot volledigheid. Uit de tabel blijkt heid kan onderzoek naar claims en onderzoek naar de apriori kansen op een materiële fout met betrekking tot volledigheid behulpzaam zijn.

\section{Besluit}

Ik hoop dat ik u vanmiddag op overzichtelijke wijze door de drie voorbeelden van onderzoek naar de activiteiten van accountants heb geleid. Het onderscheid tussen de drie niveaus van analyse is gemaakt om mijn gedachten op overzichtelijke wijze aan te bieden. In werkelijkheid zijn er natuurlijk veel verbanden tussen de drie niveaus. 
Deze komen bijvoorbeeld tot uitdrukking bij de analyse van de toegenomen vraag naar accountantscontrole door kleinere cliënten. Deze toegenomen vraag heeft effecten op alle drie de niveaus. $\mathrm{Zij}$ heeft effecten voor de structuur van de markt en de carrièremogelijkheden van accountants. Tevens heeft de vraag door kleinere cliënten effecten voor de wijze waarop de accountantscontrole wordt uitgevoerd.

Zoals eerder gezegd heb ik de voorbeelden gebruikt om $u$ van twee gedachten te overtuigen. Ten eerste heb ik $u$ ervan willen overtuigen dat meer economisch gefundeerd empirisch onderzoek naar de activiteiten van accountants wenselijk is. Met de drie voorbeelden heb ik getracht aan te geven dat met het perspectief van de accountant als koopman nuttige inzichten kunnen worden verkregen. Op het niveau van de markt heeft dit onderzoek reeds een goede staat van dienst. Op het niveau van het controleproces is dit onderzoek net begonnen en op het niveau van het kantoor is er eigenlijk nog niets. Uiteraard dienen bij toekomstig onderzoek de kleinere cliënt en het kleinere accountantskantoor onderwerp van studie te zijn. Vooral met het eerste en derde voorbeeld heb ik getracht te laten zien dat de accountantscontrole in het midden- en kleinbedrijf een interessant veld van onderzoek is.

Ten tweede heb ik $u$ ervan willen overtuigen dat de activiteiten van accountants meer en meer bloot staan aan de tucht van de markt. De belangrijke veranderingen in de Nederlandse markt voor accountantscontrole zijn gedokumenteerd in het eerste voorbeeld over toetreding. Verwacht kan worden dat de substantiële toetreding in recente jaren heeft geleid tot meer concurrentie op prijs en kwaliteit. Zeff (1992) heeft deze toenemende commercialisatie van de activiteiten van accountants pessimistisch de "decline of professionalism" genoemd. Ik deel zijn pessimisme niet omdat ik geen aanwijzingen heb dat commer- 


\section{Dominees op de markt}

cialisatie van accountantsdiensten leidt tot onwenselijke effecten. Derhalve zie ik er geen kwaad in dat de dominee op financieel-economisch gebied gedwongen wordt als koopman te werken. 


\section{Dominees op de markt}

\section{Dankwoord}

De spreekwoordelijke saaiheid van accountants is in voorgaande oraties van twee van mijn collega's ruimschoots aan bod gekomen. De eerlijkheid gebiedt te zeggen dat als accountants saai zijn, dan zijn wij als onderzoekers van activiteiten van accountants het natuurlijk maximum op de schaal van saaie mensen. En inderdaad, onderzoeker worden van het gedrag van accountants wordt weinig genoemd als je kinderen vraagt naar hun gedroomde toekomstige functie. Met deze opmerkingen wil ik niet suggereren dat ik op belangrijke momenten in mijn carrière heb zitten slapen. Integendeel.

Enkele mensen die bij belangrijke stappen in mijn carrière betrokken zijn geweest verdienen het om vermeld te worden. Allereerst wil ik graag de NOvAA danken voor het instellen van de bijzondere leerstoel en voor het in mij gestelde vertrouwen om deze te bezetten. Ik wil vooral Harry Geerlofs, Berend Jansen, Peter Legerstee en Frans van Schaik danken voor hun persoonlijke inzet bij de totstandkoming van deze bijzondere leerstoel. Het feit dat een jonge beroepsorganisatie ervoor gekozen heeft om met de jongste economische faculteit in zee te gaan is voor mij geen toeval. Beide organisaties hebben op daadkrachtige wijze de instelling van de bijzondere leerstoel aangepakt. Vanzelfsprekend wil ik het College van Bestuur danken voor het instellen van de andere leerstoel en voor het in mij gestelde vertrouwen.

Aan het begin van mijn academische carrière hebben Willem Buijink, Jan van de Poel en Arnold Schilder mij geholpen de juiste beslissingen te nemen. Jan van de Poel had een beter inzicht in mijn talenten dan ikzelf. Na mijn doctoraalstudie bedrijfseconomie heeft hij mij overgehaald om te gaan promoveren, iets waar ik zelf niet aan had gedacht. Later heeft hij mij, samen met Arnold Schilder, verleid om 
directeur te worden van het MARC. Willem Buijink dank ik voor het mij bijbrengen van de juiste attitude voor het doen van onderzoek.

De collega's van de faculteit, en die van het MARC en de sectie Berichtgeving in het bijzonder, wil ik allen graag danken voor het creëren van een stimulerende omgeving voor het doen van onderzoek en het geven van onderwijs. In het bijzonder wil ik Roger Dassen, Piet Eichholtz, Roger Meuwissen, René Olie en Luc Quadackers danken voor hun ondersteuning bij de totstandkoming van deze oratie.

Vrienden, familie en in het bijzonder mijn ouders dank ik voor hun enthousiaste belangstelling voor mijn werk. Tot slot wil ik natuurlijk Mariëlle danken voor haar genereuze ondersteuning. Zij lijdt het meest onder mijn belangstelling voor de wetenschap en verdient de meeste dank. Terzijde zij opgemerkt dat zij de titel van mijn proefschrift maar nooit weet te onthouden. Daarmee heeft zij een stilzwijgend oordeel gegeven over hoe pakkend die titel was. Ik hoop dat ik het deze keer beter heb gedaan.

Ik heb gezegd. 


\section{Literatuur}

Bedard, J., "An archival study of audit program planning", Auditing: A Journal of Practice and Theory 9, no. 1, Fall 1989, blz. 57-71.

Buijink, W.F.J., Empirical Financial Accounting Research: Compliance with regulation, distributional properties of financial ratios and demand for external auditing, Maastricht: Datawyse/UPM, 1992.

Buijink, W.F.J. en S.J. Maijoor, Entry, Exit, and Market Share Mobility in an Audit Market: Evidence from the Netherlands, MARCRM-1993/010, 1993.

Copley, P.A. en M.S. Doucet, "The impact of competition on the quality of governmental audits ", Auditing: A Joumal of Practice and Theory 12, no. 1, Spring 1993, blz. 88-98.

Dassen, R.J.M., Audit Quality: An empirical study of the attributes and determinants of audit quality perceptions, Landgraaf: Groenevelt B.V., 1995.

Davidson, R.A. en W.E. Gist, "Empirical evidence on the functional relation between audit planning and total audit effort", te verschijnen in de Journal of Accounting Research.

DiPietro, J.D., T.J. Mock en A. Wright, "An investigation of adaptability in evidential planning", in: R.P. Srivastava (ed.), Proceedings of the 1994 Deloitte \& Touche/University of Kansas Symposium on Auditing Problems XII, May 1994, blz. 73-91. 


\section{Dominees op de markt}

Gilson, J. en R.H. Mnookin, "Coming of age in a corporate law firm: the economics of associate career patterns", Stanford Law Review 41, February 1989, blz. 567-595.

Langendijk, H.P.A.J., De markt voor wettelijk verplichte accountantscontrole in Nederland, Den Haag: Delwel B.V., 1994.

Maijoor, S.J., "Economic effects of accounting regulation for public accountants", Accounting and Business Research 24, no. 95, Summer 1994, blz. 267-276.

Maijoor, S.J. en R.H.G. Meuwissen, Mobility of Auditors and the Nature of Audit Services: Exploratory evidence from the Dutch audit market, MARC-RM-1993/012, 1993.

Mock, T.J. en A. Wright, "An exploratory study of auditor's evidential planning judgments", Auditing: A Journal of Practice \& Theory 12, no. 2, Fall 1993, blz. 39-61.

Moizer, P., "State of the art in audit market research", The European Accounting Review 1, no. 2, December 1992, blz. 333-348.

O'Keefe, T.B., D.A. Simunic en M.T. Stein, "The production of audit services: evidence from a major public accounting firm", Journal of Accounting Research 32, Autumn 1994, blz. 241-261.

Quadackers, L.M. en S.J. Maijoor, Audit Risk and Audit Programs, Working Paper, 1995. 


\section{Dominees op de markt}

Quadackers, L.M., T.J. Mock en S.J. Maijoor, "Audit Risk and Audit Programs: Archival evidence from four Dutch audit firms", te verschijnen in The European Accounting Review.

Simunic, S.A. en M.T. Stein, "The auditing marketplace: exploring the economics of auditing services in the real world", CA Magazine, January/February 1995, blz. 53-58.

St. Pierre, K. en J.A. Anderson, "An analysis of the factors associated with lawsuits against public accountants", The Accounting Review 59, no. 2, April 1984, blz. 242-263.

Wallage, Ph., "Internationalising audit: a study of audit approaches in the Netherlands", The European Accounting Review 2, no. 3, December 1993, blz. 555-578.

Wieleman, H.H.H. en C.A.J. Kuijpers, "Claims en risico's in de accountantspraktijk", in: Risico's en oordeelsvorming in de accountantspraktijk, Amsterdam: Limperg Instituut, 1990, blz. 150-159.

Yardley, J.A., N.L. Kauffman, T.D. Cairney en W.D. Albrecht, "Supplier behavior in the U.S. audit market", Journal of Accounting Literature 11, 1992, blz. 151-184.

Zeff, S.A., "The decline of professionalism", De Accountant nr. 5, januari 1992, blz. 264-267. 